Ass. Prof. Canan Yildiz Cicekler ${ }^{1}$

Original scientific paper Necmettin Erbakan University, Department of Preschool Education

Konya, Turkey

Prof. Dr. Neriman Aral ${ }^{2}$

Ankara University, Department of Child Development

Ankara, Turkey

\title{
INVESTIGATION OF THE RELATIONSHIP BETWEEN CREATIVITY OF PRESCHOOL CHILDREN AND REFLECTIVE THINKING TENDENCIES OF TEACHERS
}

\begin{abstract}
The aim of the study is to examine the relationship between preschool teachers' reflective thinking tendencies and children's creativity. The study is in general screening model and was conducted with preschool teachers, and normally developing children attending kindergarten, primary school and secondary school in Konya city center in the 2020-2021 academic year. Points of continuous and purposeful thinking, open-mindedness, inquisitive and effective teaching, teaching responsibility and scientificity, being inquisitory, prescient and sincere, profession overview, which are the sub-dimensions of the reflective thinking tendency of teachers scale, were found to differ significantly. Points of continuous and purposeful thinking, open-mindedness, inquisitive and effective teaching, teaching responsibility and scientificity, being inquisitory, prescient and sincere, profession overview, which are the sub-dimensions of the reflective thinking tendency of teachers scale, were found to differ significantly according to professional seniority. When the relationship between pre-school teachers' reflective thinking tendencies and children's creativity was examined in the study, a ngative and significant relationship was found between open-mindedness, inquisitive and effective teaching, teaching responsibility and scientificity, being prescient and sincere, profession overview, which are the sub-dimensions of the reflective thinking tendency, and fluency and originalitiy, which are the sub-dimensions of creativity.
\end{abstract}

Keywords: Creativity, reflective thinking, preschool teacher, child, preschool education.

\section{Introduction}

The concept of creativity, which was the center of attention and wondered by people for centuries, continues to be important today. Traces of creative thinking can be seen in all areas from the first humans to the present. Creativity constitutes an important

1ycicekler@erbakan.edu.tr

${ }^{2}$ aralneriman@gmail.com 
basis in people's lives and development processes (Can Yasar \& Aral, 2010). Creativity is an innate ability found in every person, albeit at different levels (Aral \& Yildiz Cicekler, 2018). It is not possible to limit the concept of creativity seen in all stages of life and contributing in all areas within a narrow framework. Creativity is addressed in every part of life with its various aspects (Kuru Turasli, 2012). It is very important for children to be innovative and creative in education systems. The concept of creativity was expressed by scientists until today with various interpretations. All explanations for creativity agree that creativity means doing new, original and different things. According to scientists, it is important to create creative environments that form the basis of school systems and educational programs, as the degrees of creativity of all individuals differ from each other (Fazelian \& Azimi, 2013; Yildirim Polat, 2019).

Creative individuals can see their environment from different angles and perceive them differently. Providing appropriate environmental conditions for the development of creativity in individuals has a very important place in supporting creativity. For this reason, teachers should be self-confident, natural, sincere and quite enthusiastic in order to be able to reveal children's creativity. Since it affects the personality traits and life of preschool children in all aspects, it is very important to create creativity-enhancing environments that start from the preschool period and will continue throughout their lives (Aral, 1999; Gizir Ergen \& Koksal Akyol, 2012). After the family, teachers play an important role in creating creative environments. Teachers serve as a very important bridge in the transfer of knowledge, skills and values to children in the education system. Teachers are among the greatest values of a country's education system and the quality of education in the country varies depending on the quality of teachers and teaching (Mathew, Mathew, \& Peechattu, 2017). Today, education and training programs aim to develop the skills that enable children, one of the basic elements of the process, to think and reveal what they think. In order to improve children's thinking skills, reflective thinking should be included in educational programs (Yel \& Yigitel, 2019), and reflective thinking, which has an important place in the constructivist approach, should be actively used in learning and teaching processes (Alp \& Sahin Taskin, 2012). Reflective thinking is an indispensable element of learning processes and teachers (Tok, 2008). Reflective thinking is the ability to think carefully, effectively and consistently about reasons that will support a belief or knowledge and transmit it to the next stage (Dewey, 1910). When individuals examine their actions in depth and think about their reasons, it refers to reflective thinking (Schon, 1983). Reflective thinking is the ability of an individual to make self-criticism and to think consciously about a subject (Erol, Erol, Calisir, \& Bozan, 2019). Reflective thinking is not only a tool of practice, but a structural relationship that helps teachers to teach effectively and intelligently, away from emotions, dogmatic thoughts and prejudices (Roskos, Vukelich, \& Risko, 2001). A reflective teacher does not only work in a solution-oriented manner. They are aware of the source and influence of their actions and do not behave in the same way every day. Instead, the teacher seeks a meaning in the teaching techniques they apply to children and try to create a new theory (Rodgers, 2002). Reflective teachers, while providing their children with reflective thinking skills, support their thinking skills such as analysis, synthesis and evaluation. Thus, teachers make a great contribution to the training of individuals with the characteristics desired by productive societies (Duban \& Yanpar Yelken, 2010). As a result of the study conducted by Alp and Sahin Taskin (2012), they stated that the teachers did not have any knowledge about the concept of reflective thinking since they had not received any training on reflective thinking in their previous education processes. In the study, it was seen that although the teachers did not have sufficient knowledge about reflective thinking, they used some practices that included 
reflective thinking in their education. As a result of the study conducted by Tekeli (2016), no significant relationship was found between the number of students in preschool teachers' classrooms and their reflective thinking tendencies. Based on this information, it is seen that it is important for the quality and qualification of education that teachers with reflective thinking try to improve themselves in all activities necessary to be effective in the education and training process, and support children's development areas. The intensive emphasis on the teacher's creativity in the education system also reveals the importance of teachers' having reflective thinking. For this reason, the reflective thinking tendencies of preschool teachers in the creativity levels of preschool children were examined in the study.

\section{Method}

In the study, it was aimed to examine the relationship between the creativity levels of preschool children and the reflective thinking tendencies of preschool teachers.

\subsection{Study Model}

The relational screening model, one of the general screening models, was used in the study conducted to examine the relationship between the creativity of preschool children and the reflective thinking tendencies of teachers. General screening model is a research model that aims to describe past and present situations as they are. Relational screening model, on the other hand, is a research model that aims to determine the state of change between two or more variables (Karasar, 2016).

\subsection{Study Group}

In the 2020-2021 academic year, 281 children who attended kindergarten and nursery class in Konya city center, showed normal development and from whose families consent was obtained, and 106 preschool teachers who agreed to participate in the study were included in the study by simple random sampling method (Buyukozturk, Kilic Cakmak, Akgun, Karadeniz, \& Demirel, 2018). In the study, $47.3 \%$ of the children were girls and $52.7 \%$ were boys. $22.6 \%$ of the preschool teachers in the study group were in the $25-30$ age range, $22.6 \%$ in the $31-35$ age range, $34.0 \%$ in the $36-40$ age range, $20.8 \%$ in the 41-45 age range and all of the teachers included in the study was a woman. When the professional seniority of teachers was examined, it was determined that $16 \%$ of them had $1-5$ years of seniority, $24.5 \%$ had $6-10$ years of seniority, $28.3 \%$ had $11-15$ years of seniority, $19.8 \%$ had $16-20$ years of seniority, $11.3 \%$ had 21 years of seniority or more.

\subsection{Data Collection Tool}

In the study, the demographic information of the children and teachers included in the study was determined with the "Child and Teacher Personal Information Form" created by the researchers. The Integrated Creativity Test-Preschool (ICT-P) developed by Lee and Lee (2002) and revised by Lee (2014) and adapted to Turkish by Koyuncuoglu and Artan (2019) was used to determine the creativity levels of children. In addition, the "Reflective Thinking Tendency Scale for Teachers and Teacher Candidates (RTT)" developed by Semerci (2007) was used to examine preschool teachers' reflective thinking tendencies. Information on the scales applied to children and preschool teachers is given below; 


\section{Personal Information Form about the Child}

The personal information form about the child was created by the researchers in order to determine the demographic information of the children included in the study. It was ensured that the personal information form about the child was filled by the parents of the children.

\section{Personal Information Form about the Teacher}

It was created by the researchers to determine the age, professional seniority, etc. characteristics of the preschool teachers included in the study.

\section{Integrated Creativity Test-Preschool (ICT-P)}

Integrated Creativity Test-Preschool (ICT-P) was developed by Lee and Lee (2002), and later revised by Lee (2014). Adaptation study to Turkish was done by Koyuncuoglu and Artan (2019). This test consists of two parts as "creative thinking skill test" and "creative personality traits". The adaptation study of the section related to the "creative thinking skill test" sub-dimension of "Integrated Creativity Test-Preschool (ICT-P)" was done by Koyuncuoglu and Artan (2019). Creative thinking ability sub-dimension has two subareas as "language" and "drawing area". Language area consists of "imagination, fluency, flexibility and originality" factors. The drawing area consists of "continuation and connection, completion, new elements addition, theme, and unconventionality" sub-factors. The Integrated Creativity Test-Preschool (ICT-P) is applied to the children individually by the researcher. The language score of the scale is obtained by the total scores of four sub-factors "imagination, fluency, flexibility and originality". Drawing subdimension consists of one item and children are expected to create the pictures in ten minutes by using five different shapes. After the picture is completed, they are asked to name the picture. The drawing score consists of the sum of the scores obtained from the sub-factors of "continuation and connection, completion, new elements addition, theme, and unconventionality". Fit indexes of the scale obtained as a result of confirmatory factor analysis CMIN/DF: 1.376; RMSEA: .061; GFI: .911 and CFI: .924 were obtained. As a result of the reliability analysis of the scale, Cronbach alpha coefficients; language area is $\alpha: .999$, drawing area is $\alpha: .991$ and creativity total is $\alpha: .996$.

\section{Reflective Thinking Tendency Scale for Teachers and Candidate Teachers (RTT)}

The reflective thinking tendency scale (RTT) for teachers and candidate teachers was developed by Semerci (2007). The scale consists of seven sub-dimensions (continuous and purposeful thinking, open-mindedness, inquisitive and effective teaching, teaching responsibility and scientificity, being inquisitory, prescient and sincere, profession overview) and a total of 35 items. The scale is rated as " 5 : I totally agree, 4: I mostly agree, 3: I partially agree, 2: I mostly disagree, 1: I do not agree at all." 20 items of the scale consist of negative items that are scored in reverse and 15 consist of positive items. The Cronbach Alpha coefficient of the RTT scale is 0.908. Cronbach Alpha coefficients of the sub-dimensions is $\alpha: .794$ for continuous and purposeful thinking, is $\alpha: .712$ for open-mindedness, is $\alpha: .747$ for inquisitive and effective teaching, is $\alpha: .776$ for teaching responsibility and scientificity, is $\alpha: .742$ for inquisitory, is $\alpha$ : .668 for being prescient and sincere, is $\alpha: .357$ for profession overview. 


\subsection{Data Collection and Analysis}

The relationship between the reflective thinking tendencies of preschool teachers and the creative levels of preschool children was calculated with the Pearson correlation coefficient. Whether the creativity levels of preschool children differed significantly according to their gender was analyzed with the $\mathrm{t}$ test. In addition, the Kruskal Wallis $\mathrm{H}$ test was used because the data did not show a normal distribution in the analyzes regarding the age and professional seniority characteristics of preschool teachers and the sub-dimensions of the reflective thinking tendency scale.

\section{Findings}

In this part of the study, according to the relationship between the creativity levels of preschool children and the reflective thinking tendencies of preschool teachers, and demographic variables the results of the analysis made on the creativity levels of the children and the reflective thinking tendencies of preschool teachers are presented and explained in the tables below.

Table 1. Correlation values between pre-school teachers' reflective thinking tendencies and preschool children's creativity levels

\begin{tabular}{|c|c|c|c|c|c|c|c|}
\hline & $\begin{array}{c}\text { Continuou } \\
\text { s and } \\
\text { purposefu } \\
\text { I thinking }\end{array}$ & $\begin{array}{l}\text { Open- } \\
\text { mindedn } \\
\text { ess }\end{array}$ & $\begin{array}{l}\text { Inquisiti } \\
\text { ve and } \\
\text { effectiv } \\
\text { e } \\
\text { teaching }\end{array}$ & $\begin{array}{l}\text { Teaching } \\
\text { responsibili } \\
\text { ty and } \\
\text { scientificity }\end{array}$ & $\begin{array}{l}\text { Inquisito } \\
\text { ry }\end{array}$ & $\begin{array}{l}\text { Being } \\
\text { prescie } \\
\text { nt and } \\
\text { sincere }\end{array}$ & $\begin{array}{c}\text { Profession } \\
\text { overview }\end{array}$ \\
\hline Imagination & -.045 & -.170 & -.161 & -.094 & -.078 & -.101 & -.125 \\
\hline Flexibility & .022 & -.086 & -.096 & -.037 & -.031 & -.059 & -.112 \\
\hline Fluency & -.188 & $-.232^{*}$ & $-.246 *$ & $-.232 *$ & $-.249^{*}$ & $-.253^{* *}$ & $-.201^{*}$ \\
\hline Originality & -.181 & $-.202 *$ & $-.194^{*}$ & $-.201 *$ & $-.217^{*}$ & $-.221^{*}$ & -.172 \\
\hline $\begin{array}{l}\text { Continuation } \\
\text { /connection }\end{array}$ & .079 & .066 & .081 & -.022 & -.016 & -.012 & .005 \\
\hline Completion & -.142 & -.177 & -.173 & -.191 & -.094 & -.127 & -.107 \\
\hline $\begin{array}{l}\text { New } \\
\text { elements } \\
\text { addition }\end{array}$ & -.076 & -.142 & -.134 & -.183 & -.096 & -.083 & -.049 \\
\hline Theme & .114 & .064 & .051 & .047 & .106 & .021 & .172 \\
\hline $\begin{array}{l}\text { Unconventi } \\
\text { nality }\end{array}$ & -.128 & -.101 & -.113 & -.187 & $-.198^{*}$ & -.185 & -.173 \\
\hline
\end{tabular}

When Table 1 is examined, between fluency, which is one of the sub-dimensions of the pre-school children's creativity scale, and open-mindedness ( $r=-.232, p<.05)$, inquisitive and effective teaching $(r=-.246, p<.05)$, teaching responsibility and scientificity $(r=-.232$, $p<.05)$, inquisitory $(r=-.249, p<.05)$, being prescient and sincere $(r=-.253, p<.01)$, profession overview $(r=-.201, p<.05)$, which are the sub-dimensions of preschool teachers' reflective thinking tendency scale, were found a negative and significant relationship. Between originality, which is one of the sub-dimensions of the pre-school children's creativity scale, and open-mindedness ( $r=-.202, p<.05)$, inquisitive and effective teaching $(r=-.194, p<.05)$, teaching responsibility and scientificity $(r=-.201$, $p<.05)$, inquisitory $(r=-.217, p<.05)$, being prescient and sincere $(r=-.221, p<.05)$, which are the sub-dimensions of preschool teachers' reflective thinking tendency. A negative and significant relationship was found between unconventionality, which is one of the subdimensions of the pre-school children's creativity scale, and inquisitory $(r=-.198, p<.05)$, which is one of the sub-dimensions of the teachers' reflective thinking tendency scale. 
Table 2. T-test results associated with creativity scale sub-dimensions according to preschool children's gender

\begin{tabular}{llccccc}
\hline & Gender & $\mathrm{n}$ & $\overline{\mathrm{X}}$ & $\mathrm{S} . \mathrm{S}$ & $\mathrm{t}$ & $\mathrm{P}$ \\
\hline Imagination & Female & 133 & 3.79 & 2.28 & 1.68 & .094 \\
& Male & 148 & 3.40 & 1.59 & & \\
\hline Flexibility & Female & 133 & 1.78 & .81 & -.445 & .657 \\
& Male & 148 & 1.83 & .75 & & \\
\hline Fluency & Female & 133 & 14.43 & 6.68 & .544 & .587 \\
& Male & 148 & 14.01 & 6.33 & & \\
\hline Originality & Female & 133 & 7.90 & 5.11 & .950 & .343 \\
& Male & 148 & 7.35 & 4.61 & & \\
\hline Continuation/connection & Female & 133 & 0.76 & .97 & -.202 & .840 \\
& Male & 148 & 0.76 & .97 & & \\
\hline Completion & Female & 133 & 1.71 & .75 & -1.37 & .169 \\
& Male & 148 & 1.84 & .82 & & \\
\hline New elements addition & Female & 133 & 1.31 & 1.18 & -1.30 & .194 \\
& Male & 148 & 1.50 & 1.18 & & \\
\hline Theme & Female & 133 & .78 & 1.20 & -1.94 & .053 \\
& Male & 148 & 1.08 & 1.30 & & \\
\hline Unconventionality & Female & 133 & 1.62 & .84 & 1.42 & .155 \\
& Male & 148 & 1.47 & .84 & & \\
\hline
\end{tabular}

Imagination ( $\left.t_{279}=1.68, p>.05\right)$, flexibility $\left(t_{279}=-.445, p>.05\right)$, fluency $\left(t_{279}=.544, p>.05\right)$, originality $\left(t_{279}=.950, p>.05\right)$, continuation/connection $\left(t_{279}=-.202, p>.05\right)$, completion $\left(t_{279}=-1.37, p>.05\right)$, new elements addition $\left(t_{279}=-1.30, p>.05\right)$, theme $\left(t_{279}=-1.94\right)$ and unconventionality $\left(t_{279}=1.42, p>.05\right)$, which are creativity scale sub-dimensions according to preschool children's gender, were not found a significant difference.

Table 3. Kruskal Wallis $H$ test results associated with the sub-dimensions of the reflective thinking tendency scale according to preschool teachers' ages

\begin{tabular}{|c|c|c|c|c|c|c|c|}
\hline $\begin{array}{l}\text { Reflective Thinking } \\
\text { Tendency }\end{array}$ & Age & $\mathrm{n}$ & Mean Rank & sd & $\mathrm{X}^{2}$ & $P$ & $\begin{array}{l}\text { Significance } \\
\text { (Bonferroni) }\end{array}$ \\
\hline \multirow{4}{*}{$\begin{array}{l}\text { Continuous and } \\
\text { Purposeful } \\
\text { Thinking }\end{array}$} & $25-30$ & 24 & 49.46 & \multirow{4}{*}{3} & \multirow{4}{*}{13.219} & \multirow{4}{*}{$.004 *$} & \multirow{4}{*}{$2-4$} \\
\hline & $31-35$ & 24 & 39.71 & & & & \\
\hline & $36-40$ & 36 & 54.11 & & & & \\
\hline & $41-45$ & 22 & 71.95 & & & & \\
\hline \multirow{4}{*}{ Open-mindedness } & $25-30$ & 24 & 47.67 & \multirow{4}{*}{3} & \multirow{4}{*}{16.286} & \multirow{4}{*}{$.001 *$} & \multirow{4}{*}{$2-4$} \\
\hline & $31-35$ & 24 & 36.06 & & & & \\
\hline & $36-40$ & 36 & 59.42 & & & & \\
\hline & $41-45$ & 22 & 69.20 & & & & \\
\hline \multirow{4}{*}{$\begin{array}{l}\text { Inquisitive and } \\
\text { effective teaching }\end{array}$} & $25-30$ & 24 & 46.15 & \multirow{4}{*}{3} & \multirow{4}{*}{$15 \cdot 713$} & \multirow{4}{*}{$.001 *$} & \multirow{4}{*}{$1-4$} \\
\hline & $31-35$ & 24 & 3879 & & & & \\
\hline & $36-40$ & 36 & 57.33 & & & & \\
\hline & $41-45$ & 22 & 71.30 & & & & \\
\hline \multirow{4}{*}{$\begin{array}{c}\text { Teaching } \\
\text { Responsibility and } \\
\text { Scientificity }\end{array}$} & $25-30$ & 24 & 53.21 & \multirow{4}{*}{3} & \multirow{4}{*}{12.587} & \multirow{4}{*}{$.006 *$} & \multirow{4}{*}{$2-4$} \\
\hline & $31-35$ & 24 & 36.83 & & & & \\
\hline & $36-40$ & 36 & 55.68 & & & & \\
\hline & $41-45$ & 22 & 68.43 & & & & \\
\hline \multirow{4}{*}{ Inquisitory } & $25-30$ & 24 & 53.52 & \multirow{4}{*}{3} & \multirow{4}{*}{12.527} & \multirow{4}{*}{$.006 *$} & \multirow{4}{*}{$2-4$} \\
\hline & $31-35$ & 24 & 38.40 & & & & \\
\hline & $36-40$ & 36 & 53.24 & & & & \\
\hline & $41-45$ & 22 & 70.39 & & & & \\
\hline \multirow{4}{*}{$\begin{array}{l}\text { Being Prescient and } \\
\text { Sincere }\end{array}$} & $25-30$ & 24 & 53.67 & \multirow{4}{*}{3} & \multirow{4}{*}{7.852} & \multirow{4}{*}{$.049^{*}$} & \multirow{4}{*}{$2-4$} \\
\hline & $31-35$ & 24 & 39.90 & & & & \\
\hline & $36-40$ & 36 & 55.64 & & & & \\
\hline & $41-45$ & 22 & 64.66 & & & & \\
\hline
\end{tabular}




\begin{tabular}{cccccccc}
\hline & $25-30$ & 24 & 49.71 & & & & \\
Profession & $31-35$ & 24 & 37.15 & 3 & 15.278 & $.002 *$ & $2-4$ \\
Overview & $36-40$ & 36 & 56.56 & & & & \\
& $41-45$ & 22 & 70.48 & & & & \\
\hline${ }^{*} \mathrm{p}<.05$ & & & & & & &
\end{tabular}

Point avareges of continuous and purposeful thinking ( $\left.X_{2}=13.21, s d=3, p<.05\right)$, openmindedness $\left(X_{2}=16.28, s d=3, p<.05\right)$, inquisitive and effective teaching $\left(X_{2}=15.71\right.$, sd $=3$, $p<.05)$, teaching responsibility and scientificity $\left(X_{2}=12.58, s d=3, p<.05\right)$, inquisitory $\left(X_{2}=12.52, s d=3, p<.05\right)$, being prescient and sincere $\left(X_{2}=7.85, s d=3, p<.05\right)$, profession overview $\left(X_{2}=15.27, s d=3, p<.05\right)$, which are creativity scale sub-dimensions according to preschool children's ages, were found to differ significantly. Individuals between the ages of 41-45 had higher reflective thinking tendencies than individuals between the ages of 31-35 in the sub-dimensions of continuous and purposeful thinking, openmindedness, teaching responsibility and scientificity, being prescient and sincere, inquisitory, profession overview according to the results of the Bonferroni test in the multiple comparison test to determine which group the difference originates from , and it was observed that individuals between the ages of 41-45 had higher reflective thinking tendencies than individuals between the ages of 25-30 in the inquisitive and effective teaching sub-dimension.

Table 4. The Kruskal Wallis H-test results associated with the sub-dimensions of the reflective thinking tendency scale according to the professional seniority of preschool teachers

\begin{tabular}{|c|c|c|c|c|c|c|c|}
\hline $\begin{array}{l}\text { Reflective } \\
\text { Thinking } \\
\text { Tendency } \\
\end{array}$ & $\begin{array}{l}\text { Professional } \\
\text { Seniority }\end{array}$ & $\mathrm{N}$ & $\begin{array}{l}\text { Mean } \\
\text { Rank }\end{array}$ & sd & $\mathrm{X}^{2}$ & $\mathrm{p}$ & $\begin{array}{l}\text { Significance } \\
\text { (Bonferroni) }\end{array}$ \\
\hline \multirow{5}{*}{$\begin{array}{l}\text { Continuous and } \\
\text { Purposeful } \\
\text { Thinking } \\
\end{array}$} & $1-5$ years & 17 & 47.82 & \multirow{5}{*}{4} & \multirow{5}{*}{24.261} & \multirow{5}{*}{$.000 *$} & $2-4$ \\
\hline & 6-10 years & 26 & 46.90 & & & & $2-5$ \\
\hline & $11-15$ years & 30 & 39.12 & & & & $3-4$ \\
\hline & $16-20$ years & 21 & 73.02 & & & & $3-5$ \\
\hline & 21 years and over & 12 & 77.63 & & & & \\
\hline \multirow{5}{*}{$\begin{array}{l}\text { Open- } \\
\text { mindedness }\end{array}$} & $1-5$ years & 17 & 51.21 & \multirow{5}{*}{4} & \multirow{5}{*}{21.803} & \multirow{5}{*}{$.000 *$} & $1-4$ \\
\hline & 6-10 years & 26 & 41.98 & & & & $2-4$ \\
\hline & 11-15 years & 30 & 43.05 & & & & $2-5$ \\
\hline & $16-20$ years & 21 & 71.83 & & & & $3-4$ \\
\hline & 21 years and over & 12 & 75.75 & & & & $3-5$ \\
\hline \multirow{6}{*}{$\begin{array}{l}\text { Inquisitive and } \\
\text { effective } \\
\text { teaching }\end{array}$} & $1-5$ years & 17 & 44.12 & \multirow{6}{*}{4} & \multirow{6}{*}{26.221} & \multirow{6}{*}{$.000 *$} & $1-4$ \\
\hline & 6-10 years & 26 & 46.96 & & & & $1-5$ \\
\hline & $11-15$ years & 30 & 40.52 & & & & $2-4$ \\
\hline & $16-20$ years & 21 & 74.90 & & & & $2-5$ \\
\hline & 21 years and over & 12 & 75.96 & & & & $3-4$ \\
\hline & & & & & & & $3-5$ \\
\hline \multirow{5}{*}{$\begin{array}{l}\text { Teaching } \\
\text { Responsibility } \\
\text { and Scientificity }\end{array}$} & $1-5$ years & 17 & 54.88 & \multirow{5}{*}{4} & \multirow{5}{*}{26.750} & \multirow{5}{*}{$.000 *$} & \\
\hline & 6-10 years & 26 & 48.19 & & & & $2-4$ \\
\hline & $11-15$ years & 30 & 34.93 & & & & $3-4$ \\
\hline & $16-20$ years & 21 & 75.67 & & & & $3-5$ \\
\hline & 21 years and over & 12 & 70.67 & & & & \\
\hline \multirow{8}{*}{ Inquisitory } & $1-5$ years & 17 & 53.88 & \multirow{5}{*}{4} & \multirow{5}{*}{31.156} & \multirow{5}{*}{$.000 *$} & \\
\hline & 6-10 years & 26 & 49.38 & & & & $2-4$ \\
\hline & 11-15 years & 30 & 32.80 & & & & $3-4$ \\
\hline & $16-20$ years & 21 & 77.00 & & & & $3-5$ \\
\hline & 21 years and over & 12 & 72.50 & & & & \\
\hline & $1-5$ y years & 17 & 55.56 & & & & \\
\hline & $6-10$ years & 26 & 49.44 & & & & $2-4$ \\
\hline & 11-15 years & 30 & 37.38 & 4 & 19.421 & $.001 *$ & $3-4$ \\
\hline
\end{tabular}




\begin{tabular}{|c|c|c|c|c|c|c|c|}
\hline \multirow[t]{2}{*}{$\begin{array}{l}\text { Being Prescient } \\
\text { and Sincere }\end{array}$} & $\begin{array}{l}16-20 \text { years } \\
21 \text { years and over }\end{array}$ & $\begin{array}{l}21 \\
12\end{array}$ & $\begin{array}{l}73.45 \\
64.75\end{array}$ & & & & \\
\hline & 1-5 years & 17 & 48.65 & & & & $1-5$ \\
\hline & $6-10$ years & 26 & 47.48 & & & & $2-4$ \\
\hline \multirow{3}{*}{$\begin{array}{l}\text { Profession } \\
\text { Overview }\end{array}$} & $11-15$ years & 30 & 38.08 & 4 & 27.020 & $.000 *$ & $2-5$ \\
\hline & $16-20$ years 21 & 21 & 72.17 & & & & $3-4$ \\
\hline & years and over & 12 & 79.29 & & & & $3-5$ \\
\hline
\end{tabular}

${ }^{*} \mathrm{p}<.05$

Point means of continuous and purposeful thinking $(X 2=24.261, s d=4, p<.05)$, openmindedness $\left(X_{2}=21.803, s d=4, p<.05\right)$, inquisitive and effective teaching $\left(X_{2}=26.221\right.$, $s d=4, p<.05)$, teaching responsibility and scientificity $(X 2=26.750, s d=4, p<.05)$, inquisitory $\left(X_{2}=31.156, s d=4, p<.05\right)$, being prescient and sincere $\left(X_{2}=19.421\right.$, $s d=4$, $p<.05)$, profession overview $\left(X_{2}=27.020, s d=4, p<.05\right)$, which are reflective thinking tendency sub-dimensions according to preschool teachers' ages, were found to differ significantly. According to the results of the Bonferroni test in the multiple comparison test to determine which group the difference originates from the scores of teachers who have professional seniority of 16-20 years and 21 years and over were higher than those with 6-10 years of professional seniority in the continuous and purposeful thinking sub-dimension ,and it was found that the scores of the teachers who had 16-20 years and 21 years and over of professional seniority were higher than those with 11-15 years of professional seniority. The scores of teachers who have professional seniority of 1620 years were higher than those with 1-5 years of professional seniority, and the scores of teachers who have professional seniority of 16-20 years and 21 years and over were higher than those with 6-10 years of professional seniority, and the scores of teachers who have professional seniority of 16-20 years and 21 years and over were higher than those with 11-15 years of professional seniority in open-mindedness sub-dimension. The scores of teachers who have professional seniority of 16-20 years and 21 years and over were higher than those with 1-5 years of professional seniority, and the scores of teachers who have professional seniority of 16-20 years and 21 years and over were higher than those with 6-10 years of professional seniority, and the scores of teachers who have professional seniority of 16-20 years and 21 years and over were higher than those with 11-15 years of professional seniority in inquisitive and effective teaching subdimension. The scores of teachers who have professional seniority of 16-20 years were higher than those with 6-10 years of professional seniority, and the scores of teachers who have professional seniority of 16-20 years and 21 years and over were higher than those with 11-15 years of professional seniority in teaching responsibility and scientificity and inquisitory sub-dimension. The scores of teachers who have professional seniority of 1-5 years were higher than those with 6-10 years of professional seniority, and the scores of teachers who have professional seniority of 16-20 years were higher than those with 11-15 years of professional seniority in being prescient and sincere subdimension. The scores of teachers who have professional seniority of 21 years and over were higher than those with 1-5 years of professional seniority, and the scores of teachers who have professional seniority of 16-20 years and 21 years and over were higher than those with 6-10 years of professional seniority, and the scores of teachers who have professional seniority of 16-20 years and 21 years and over were higher than those with 11-15 years of professional seniority in profession overview sub-dimension.

\section{Discussion}


When the relationship between the reflective thinking tendencies of preschool teachers and the creativity levels of the children was examined, it is seen that there is a negative and significant relationship between open-mindedness, inquisitive and effective teaching, teaching responsibility and scientificity, being prescient and sincere, profession overview, which are the sub-dimensions of reflective thinking tendency scale, and fluency and originality, which are the sub-dimensions of creativity scale. It is seen that there is a negative and significant relationship between inquisitory, which is one of the sub-dimensions of the reflective thinking tendency scale, and fluency, originality and unconventionality, which are the sub-dimensions of the creativity scale.

The perspective of the individual's family towards education and the attitudes and behaviors of relevant teachers are among the factors that affect creativity (Darica, 2003). It is very important to know creativity in education and to contribute to the progress of creativity by providing suitable environmental conditions to individuals. Education should have features to reveal the creativity in people (Tuna and Temizkalp, 2013). When designing learning-related processes, it is of great importance to know children well for the creation of creative products (Leggett, 2017). The creativity ability of the children can be carried to a higher level with the adequate education and a welleducated teacher (Turla, 2004). Their innate curiosity and desire to explore should not be quenched, information and environments that will motivate them and reveal their creativity should be presented to children in the education system (Buyurgan and Buyurgan, 2012). Teachers' behaviours and attitudes in and out of the classroom have a great impact on children's creativity (Yenilmez and Yolcu, 2007). In the study, a negative and significant relationship was obtained between open-mindedness, inquisitive and effective teaching, teaching responsibility and scientificity, being prescient and sincere, profession overview and inquisitory, which are the sub-dimensions of the reflective thinking tendency scale, and fluency, originality and unconventionality, which are the sub-dimensions of creativity scale. This situation can be explained by the fact that teachers do not have sufficient reflective thinking as a result of performing children's fluent, original and unconventional thinking products and behaviors.

In the study, it is seen that the sub-dimensions of the creativity scale such as "imagination, flexibility, fluency, originality, continuation/connection, completion, new elements addition, theme and unconventionality" do not differ in children significantly according to their gender. It is seen that different results were obtained in many national and international studies on whether there is a difference between creativity and gender. There are also studies that make a difference between creativity and gender in favor of girls, as well as studies which do not make a difference (Aral, 1996; Besancon \& Lubart, 2008; Cakmak, 2005; Dincer, 1993) (Argun, 2004; Can Yasar \&Aral, 2010; Çagatay Aral, 1990; Garaigordobil, 2006; Gizir Ergen and Koksal Akyol, 2012; Gonen, Uzmen, Akcin, \& Ozdemir, 1993; Gonen, Yildiz Cicekler, Akyuz, Arslan Celik, \& Baydemir, 2011; Hirschman, 2000; Oncu, 2000; Reese, Lee, Cohen, \& Puckett, 2001; Sonmaz, 2002; Tekin, 2008). It is emphasized that creativity is innate and cannot be learned, but can be developed with appropriate environment and stimulating support (Cagdas, Albayrak, \& Cantekinler, 2003). In the studies, it was stated that it will be ensured that successful societies are formed by increasing the ideal development and quality of life levels in children regardless of gender as a result of the development and support of creativity, which has versatile and complex features (Cetin \& Koyuncuoglu, 2013). The fact that no difference was found in terms of gender factor in the study can be explained by conducting studies to improve children's creativity among preschool children without gender discrimination. 
Open-mindedness, continuous and purposeful thinking, inquisitive and effective teaching, teaching responsibility and scientificity, being prescient and sincere, profession overview and inquisitory, which are the sub-dimensions of teachers' reflective thinking tendencies scale differ significantly according to age and it is observed that preschool teachers between the ages of 41-45 show the highest tendency. Reflective thinking is the individuals' questioning and self-evaluation of her own learning and teaching processes by thinking in detail about their past, present and future experiences and thinking about what can be done to solve the problems that arise as a result of these (Altin and Saracaloglu, 2018). The reason for the differences in 41-45 years old preschool teachers' perspectives such as reflective thinking tendency, continuous and purposeful thinking, being open-mindedness, inquisitive and effective teaching, sustaining teaching responsibility and scientificity, being prescient, sincere and inquisitory, profession overview is the positive reflection of their learning-teaching processes and self-evaluation by using their past experiences compared to younger preschool teachers.

It is seen that there is a significant difference between open-mindedness, continuous and purposeful thinking, inquisitive and effective teaching, teaching responsibility and scientificity, being prescient and sincere, profession overview and inquisitory, which are the sub-dimensions of teachers' reflective thinking tendency scale, and the professional seniority variable of preschool teachers. It is seen that preschool teachers who have 1620 years of professional seniority have the highest mean in the sub-dimensions of teaching responsibility and scientificity, being prescient, sincere and inquisitory while preschool teachers who have 21 years and over of professional seniority show the highest tendency in the sub-dimensions of continuous and purposeful thinking, openmindedness, inquisitive and effective teaching and profession overview. According to Roskos, Vukelich and Risko (2001), training teachers who have reflective thinking and critical thinking skills is very important. Teachers who have reflective thinking ability should have the properties such as creating a new meaning by making sense of their experiences, thinking systematically, meticulously and well-disciplined, interacting with other people in order to realize their own thoughts in society, acting with attitudes that value the personal and intellectual development of the self and others (Rodgers, 2002). Teachers who use reflective thinking perceive problems, define and make generalizations. At the same time, they use this process to make changes and developments in their professional understanding (Alp and Sahin Taskın, 2012). Daudelin (1996) discusses the reflection process as defining problems by coming together, analyzing the problem, formulating and testing a provisional theory, and taking action. The high score mean of preschool teachers with professional seniority can be explained by the efforts to continue the process in the most beneficial way by following the development-change and acting with more systematical, well-disciplined behaviours in situations requiring responsibility related to the profession as a result of the experiences and experiences gained during the profession.

\section{Conclusion and Suggestions}

In the study, it was found that there was a negative and significant relationship between open-mindedness, inquisitive and effective teaching, teaching responsibility and scientificity, being prescient and sincere, profession overviews, which are the subdimensions of reflective thinking tendency scale, and fluency and originality, which are the sub-dimensions of creativity scale. It was found that there was a negative and 
significant relationship between inquisitory, which is one of the sub-dimensions of the reflective thinking tendency scale, and fluency, originality and unconventionality, which are the sub-dimensions of the creativity scale. In the study, it was determined that the sub-dimensions of the creativity scale such as imagination, flexibility, fluency, originality, continuation/connection, completion, new elements addition, theme and unconventionality did not differ in preschool children significantly according to their gender. It was found that open-mindedness, continuous and purposeful thinking, inquisitive and effective teaching, teaching responsibility and scientificity, being prescient and sincere, profession overview and inquisitory, which are the subdimensions of preschool teachers' reflective thinking tendencies scale differ significantly according to their age. In line with the results obtained, trainings about the importance, necessity and application methods of reflective thinking in education can be organized for preschool teachers who have just started working. Preschool teachers can give more places to practices involving reflective thinking skills in their classroom education. In addition, activities or practices with parental participation can be included to support the creative thinking skills of preschool children.

\section{References:}

Alp, S. \& Sahin Taskin, C. (2012). Elestirel dusunme ve problem cozme: ogretmenlerinin yansitici dusunceyi uygulamalari. Buca Egitim Fakultesi Dergisi. 33, 134-146.

Altin, M. \& Saracaloglu, A. S. (2018). Yaratici, elestirel ve yansitici dusunme: benzerliklerfarkliliklar. Uluslararası Guncel Egitim Arastırmalari Dergisi (UGEAD), 4(1), 1-9.

Aral, N. (1996). Dokuz ve on dort yaslarindaki cocuklarin yaraticiliklari ile sosyoekonomik duzey ve cinsiyet arasindaki iliskinin incelenmesi. Egitim ve Bilim, 20(101), 65-72.

Aral, N. (1999). Sanat egitimi-Yaraticilik etkilesimi. Hacettepe Universitesi Egitim Fakultesi Dergisi, 15, 11-17.

Aral, N. \& Yildiz Cicekler, C. (2018). Yaraticiliga ait zihinsel surecler ve yaraticillgin gelisimi. (ed.) E. Celebi Oncu. Yaraticilik rehberi: gelisimsel ve egitimsel alanlarda yaraticilik icinde. (36-58). Ankara: Hedef CS Yayincilik.

Argun, Y. (2004). Okul oncesi donemde yaraticilik ve egitimi. Ankara: Ani Yayincilik.

Besancon, M. \& Lubart, T. (2008). Differences in the development of creative competencies in children schooled in diverse learning environments. Learning and Individual Differences, 18, 381-389.

Buyurgan, S. \& Buyurgan, U. (2012). Sanat egitimi ve ogretimi. Ankara: Pegem Akademi.

Buyukozturk, S., Kilic Cakmak, E., Akgun, O. E., Karadeniz, S. \& Demirel, F. (2018). Bilimsel arastırma yontemleri. Ankara: Pegem Akademi.

Can Yasar, M. \& Aral, N. (2010). Yaratici dusunme becerilerinde okul oncesi egitimin etkisi. Kuramsal Egitimbilim, 3(2), 201-209.

Cagatay-Aral, N. (1990). Alt ve ust sosyo-ekonomik duzeydeki ortaokul son sinifa devam eden oğrencilerin yaratııılıkları ile ilgili alanlarının bazı degiskenlere gore incelenmesi. Unpublished doctoral dissertation, Ankara: Ankara Universitesi.

Cagdas, A., Albayrak, H. \& Cantekinler, S. (2003). Okul oncesi egitimde dramatik etkinlikler. Konya: Egitim Kitabevi.

Cakmak, A. (2005). Anasınıfina devam eden altı yasındaki koy ve kent cocuklarının yaratıcılıklarının cesitli degiskenlere gore incelenmesi (Kirikkale Ornegi). Unpublished doctoral dissertation, Ankara: Ankara Universitesi.

Cetin, Z. \& Koyuncuoglu, B. (2013). Cocuk sanat ve yaratıcllik. Ankara: Vize Yayincilik.

Darica, N. (2003).Yaratici etkinlikler uygulama kitabi. Istanbul: Morpa Kultur. 
Daudelin, M. W. (1996). Learning from experience through reflection. Organizational Dynamics, 24(3), 36-49.

Dewey, J. (1910). How we think? D. C. Heath and Co. Publishers, Boston: New York Chicago.

Dincer, D. (1993). Anaokuluna devam eden bes yas grubu cocuklarin anne-baba tutumlari ile yaratıc dusunmeleri arasındaki iliskinin incelenmesi. Unpublished master's thesis, Istanbul: Marmara Universitesi.

Duban, N. \& Yanpar Yelken T. (2010). Ogretmen adaylarinin yansitici dusunme egilimleri ve yansıtıcı ogretmen ozellikleriyle ilgili gorusleri. C.U. Sosyal Bilimler Enstitusu Dergisi, 19(2), 343-360.

Erol, M., Erol, A., Calısır, S. \& Bozan, M. (2019). Ogretmenlerinin yansitici dusunme egilimleri ile yaratıcı dusunme duzeyleri arasındaki iliskinin incelenmesi. Temel Egitim Dergisi, 1 (2),20-29.

Fazelian, P. \& Azimi, S. (2013). Creativity in schools. Procedia-Social and Behavioral Sciences. 82, 719-723.

Garaigordobil, M. (2006). Intervention in creativity with children aged 10 and 11 years: impact of a play program on verbal and graphic-figural creativity. Creativity Research Journal, 18(3), 329-345.

Gizir Ergen, Z. \& Koksal Akyol, A. (2012). Anaokuluna devam eden cocuklarin yaraticiliklarinin incelenmesi. Kuramsal Egitimbilim Dergisi, 5(2), 156-170.

Gonen M., Yildiz Cicekler, C., Akyuz, E., Arslan Celik, A. \& Baydemir, G. (2011). 5 yasındaki cocuklarin yaraticolok duzeylerinin incelenmesi. e-Journal of New World Sciences Academy, 6(1), 1185-1195.

Gonen, M., Uzmen, S., Akcin, N. \& Ozdemir, N. (1993). Anaokuluna giden 5-6 yaş cocuklarinda yaratico dusuncenin incelenmesi. Egitim ve Bilim Dergisi, 64-71.

Hirschman, E, C. (2000). Role-based models of advertising creation and production, Journal of Advertising, 18(4), 42-53.

Karasar, N. (2016). Bilimsel arastırma yontemi kavramlar teknikler ilkeler. Ankara: Nobel Yayin Dagıtım.

Koyuncuoglu, B. \& Artan, I. (2019). Turkish adaptation of Integrated Creativity TestPreschooler- ICT-P:A validity and reliability study. Global Creative Leader: Education \& Learning, 9(6), 1-17.

Kuru Turaslı, N. (2012). Erken cocukluk doneminde yaratıcllık ve gelistirilmesi. E. Celebi Oncu (Ed.). Ankara: Pegem Akademi.

Lee, S. D. \& Lee, K. H. (2002). Integrated Initiative Test Manual. Seoul: Hakmoonsa.

Lee, K. H. (2014). Integrated Creativity Test (ICT-K): Preschool. Seoul: Inpsyt.

Leggett, N. (2017). Early childhood creativity: Challenging educators in their role to intentionally develop creative thinking in children. Early Childhood Education Journal, 45(6), 845-853.

Mathew, P., Mathew, P. \& Peechattu, P. J. (2017). Reflective practices: A means to teacher development. Asia Pacific Journal of Contemporary Education and Communication Technology (APJCECT). 3(1).

Oncu, T. (2000). Anasınıfı (6 yas) duzeyindeki cocuklarin sekilsel yaraticiloklarinin cinsiyet degiskeni acısindan karsilastirolmasi. Ankara Universitesi Dil ve Tarih Cografya Fakultesi Dergisi, 40(1-2), 25-34.

Reese, H., W., Lee, L., Cohen, S. H. \& Puckett J. J. M. (2001). Effect of intellectual variables age and gender on divergent thinking in adulthood, International Journal of Behavioral Development, 25(6) 491-500.

Rodgers, C. (2002). Defining reflection: Another look at john dewey and reflective thinking. Teachers College Record, 104 (4), 842-866. 
Roskos, K., Vukelich, C. \& Risko, V. (2001). Reflection and learning to teach reading: a critical review of literacy and general teacher education studies. Journal of Literacy Research, 33(4), 595-635.

Schon, D. A. (1983). The reflective practitioner: How professionals think in action. USA: Basic Books.

Semerci, C. (2007). Ogretmen ve ogretmen adaylari icin yansitici dusunme egilimi (RTT) olceginin gelistirilmesi. Kuram ve Uygulamada Egitim Bilimleri. 7(3), 1531-1377.

Sonmaz, S. (2002). Problem cozme becerisi ile yaraticilik ve zeka arasındaki iliskinin incelenmesi. Unpublished doctoral dissertation, Istanbul: Marmara Universitesi.

Tekeli, I. (2016). Okul oncesi ogretmenlerinin yansıtici dusunme duzeyleri. Unpublished master's thesis, Burdur: Mehmet Akif Ersoy Universitesi.

Tekin, M. (2008). Orta ogretimde ogrenim goren ogrencilerden spor yapan ve yapmayanlar arasindaki yaraticilik ve coklu zeka alanlarının arastırilmasi. Unpublished doctoral dissertation, Ankara: Gazi Universitesi.

Tok, S. (2008). Yansitici dusunmeyi geligtirici etkinliklerin ogretmen adaylarının ogretmenlik meslegine yonelik tutumlarına, performanslarına ve yansitmalarina etkisi. Egitim ve Bilim, 33(149), 104-117.

Tuna, S. \& Temizkalp, G. (2013). Ogretmen adaylarinin yaraticilik duzeyleri. Egitim ve Ogretim Arastırmaları Dergisi, 1(2).

Turla, A. (2004). Cocuk ve yaratıcilık "cocugum daha yaratıcı olabilir mi?. Istanbul: Morpa Kultur Yayinlari.

Yel, M. \& Yigitel, S. (2019). Ortaogretim biyoloji dersi ogretiminde uygulanan yansitici dusunmeyi gelistirme etkinliklerinin ogrencilerin akademik basarı ve tutumlari uzerindeki etkisi. Gazi Universitesi Egitim Fakultesi Dergisi, 39(3), 1289-1317.

Yenilmez, K. \& Yolcu, B. (2007). "Ogretmen davranıslarının yaratici dusunme becerilerinin gelisimine katkisi”. Manas Sosyal Bilimler Dergisi, 18, 95-105.

Yildirim Polat, A. (2019). Cocukta sanat egitimi ve yaratıcllık. H. T. Unalan (Ed.). Anadolu Universitesi, Acık Ogretim Fakultesi Yayini, No: 2276.

\section{Biographical notes:}

Dr. Canan YILDIZ CICEKLER, PhD, Assistant Professor for Preschool Education Department of Ahmet Keleşoğlu Education Faculty of Necmettin Erbakan University in Konya, Turkey. His field of research is creativity, art and education, and visual arts.

Dr. Neriman ARAL is a Professor in the Department of Child Development at Ankara University. She has submitted papers in many international and national congresses and also organized the scientific congress. And she has many articles in international and national journals, many books and books chapters on the field. Professor Dr. Neriman Aral is currently a lecturer in the Department of Child Development at the Health Sciences Faculty of Ankara University. 